\title{
The Relationship between Learning Motivation and Learning Outcome of Junior High School Students in Yogyakarta
}

\author{
Said Alhadi \\ Guidance and Counseling Department \\ Universitas Ahmad Dahlan \\ Yogyakarta, Indonesia \\ said.alhadi@bk.uad.ac.id
}

\author{
Wahyu Nanda Eka Saputra \\ Guidance and Counseling Department \\ Universitas Ahmad Dahlan \\ Yogyakarta, Indonesia \\ wahyu.saputra@bk.uad.ac.id
}

\begin{abstract}
Qualified education is the governments' desire in the effort to support skilled human resources. One indicator of successfully qualified education is the high-level learning outcome achieved by the students. Learning outcomes are important indicators for both teacher and student. One of the factors determining students' learning outcome is learning motivation. Motivated students tend to find beneficial and meaningful academic activities for themselves. This study aims to know the relation between learning motivation and learning outcome of Junior High School students in Yogyakarta. This study applies non-experimental research through correlational design. The population of this study includes 16 Junior High Schools in Yogyakarta. By using cluster sampling, this study takes 515 students as the samples. This study employs statistical analysis technique using regression analysis. The findings of this study show that learning motivation significantly relates to the students' learning outcome in Junior Highs School of Yogyakarta. The results of research recommend every counselor at schools to manage assisted learning program that can help students to motivate themselves in improving their learning outcome.
\end{abstract}

Keywords-Learning Motivation, Learning Outcome

\section{INTRODUCTION}

The good education is the government's desire to create the quality of human. This fits Indonesia Republic President Program entitled Building Education RPJMN 2015-2019 which say "increase the quality of Indonesian people. Increasing quality of human demands with reorganize and ways of completin in education [1]. For an example, the goverment wisdom for increasing the score of the student abortion each year. The dream of Indonesian Republic is trying to make the good quality of education has not been maximal. Nasionally education in Indonesia still be low than other countries.

Micheal told that there's worst quality of education in Indonesia based on United Nation report which deals with the education program. The data from Education For All (EFA) in 2011which is released by UNESCO in New York's index of building education or Education Development Indext based on the data from 2008 was 0,934 . That point put Indonesia in 69 from 127 countries around the world [2].

One of the good indicators and the bad qualities of education in Indonesia is the students outcome. The students outcome is very important as an good indicator for both students and teachers. For the teachers, the students result can be reflection of judging the success in teaching activity. In other hand, the students result becomes the function to judge the level of skill to the students, which change to positive changes or negative changes. It needs the preparation for any components, one of the components is the study motivation.

Several experts have other opinions about the basic of study motivation. The basic of study motivation are the internal and external support to the students who are studying so they can change their behaviour with any support indicators. Another opinion started that students who motivate to learn is the students who have academic prestation and advantagous in themselves [3].

Several researches show that the student motivation is the dimention which significant for the study result. Pape, Bell and Yetkin stated that the students who have motivation can manage the time for studying, so it can make the best result [4]. Patimah says that there's relation between the study motivation with the students reslt in IPS subject class IV SDN 18/1 Desa Teluk [5]. The research by Palupi, Anitah and Budiyono specificly in SMP students shows positive with study motivation in IPA Students SMP N 1 Pacitan [6]. The other research by Amrai and friends shows that academic motivation has significant infact to the student academic prestation [7].

The motivation and the result of the student could not be separated from teacher role as the side who give learning and guidence to the students. This implicates Proses Belajar Mengajar (PBM) is the process of interaction with teacher and the students based on teaching relation which in way to get the goals [8]. In the process of learning to teach, motivation is one factor that is suspected of great influence on learning outcomes. Students with high motivation are expected to obtain good learning outcomes. The importance of student learning motivation is formed to change the learning to a more 
positive direction. Hawley stated that students who are well motivated in learning, doing more and faster activities, compared with students who are less motivated in learning. Achievements will be better if they have high motivation [9].

It has been described above that one of the components that can be used to strengthen student learning outcomes is the motivation to learn. In this article will describe the results of research trying to explain the relationship between learning motivation and learning outcomes of junior high school students in Yogyakarta. So the results of this study is expected to be the basis of counselors in schools in preparing guidance and counseling programs to improve learning motivation that impact on improving student learning outcomes in SMP Yogyakarta.

\section{RESEARCH METHODS}

This research is a non-experimental research with correlational design. Correlational design is to study the phenomenon of relationships between variables as existing or naturally [10]. Correlation statistics are used to measure the strength of a relationship or to predict effective contributions affecting variables, which is multivariate correlation statistics. Multivariate correlation statistics are used when using three or more variables [10]. Data analysis used in simple regression analysis.

The population in the study of theoretical model of learning outcomes of students of Yogyakarta Junior High School consisted of 16 schools. Based on these conditions, the population in this study using students of Junior High School of Yogyakarta City. The Sample study of Junior High School of Yogyakarta City is cluster sampling. Cluster sampling is used when samples are eligible to be selected compared to the defined individuals of the population [10]. The steps in selecting sample selection are firstly, the researcher determines the overall population of students of Junior High School of Yogyakarta City. Secondly, the researcher determines the limits of the sample size as the minimum limit of the students involved in the study. The sample size of this study uses the condition of the proportion of the population reached $95 \%$. So the minimum limit of sample usage of this research is 385 sample research. The use of error standards of $5 \%$, aims to provide a more optimal sample size.

Then the researcher took 8 State Junior High Schools in Yogyakarta City from 16 State Junior High Schools in Yogyakarta City. 8 Junior High Schools in Yogyakarta City are divided into 4 favorite Junior High schools and 4 Nonfavorite Junior High Schools, so this criteria is taken as a step to generalize the research data. Students used in this study were taken on the students of class VII and VIII of 8 junior high schools in Yogyakarta as a sample of 515 students.

Data analysis technique used in this research is statistical analysis by using regression analysis. Regression analysis used in this research is simple regression analysis. The usefulness of multiple regression analysis is to predict the value of the dependent variable (Y) if the independent variable (X).

\section{RESEARCH RESULTS AND DISCUSSION}

The results were analyzed by using simple regression analysis. Results of data analysis using SPSS obtained the following results:

TABLE I. MODEL SUMMARY

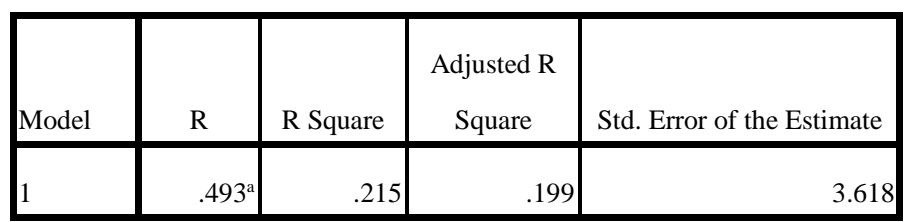

a. Predictors: (Constant), Motivasi Belajar X

The results of the data analysis above show that the motivation to learn has a significant influence on the results of junior high school students in Yogyakarta. Based on the output above, it can be seen that the coefficient of determination (R Square) of 0.215. It has the meaning that the influence of independent variables is the learning motivation of the dependent variable that is learning outcome is $21.5 \%$ and the rest is influenced by other variables.

The results above are reinforced by previous research findings that have been done. The study concluded that motivation to learn has a significant relationship to student learning outcomes [11]. If the learning motivation is high, student learning outcomes are high as well. Conversely, the lower the learning motivation of the students has parallel state in the lower of the student learning outcomes.

Subsequent research that has been done to conclude that the influence of learning motivation of fifth grade students on mathematics learning achievement in Bejirejo State Elementary School of Kunduran District Blora Regency academic year 2013/2014 [12].The study provides recommendations to the students to be able to improve motivation to learn because the motivation to learn is one of the factors that affect the achievement of students in fifth grade of Bejirejo Elementary school especially in Mathematics subjects. In addition, teachers are expected to help students not only in learning but in improving students learning motivation and approaching with parents in order to help improve students' learning motivation.

In addition, other studies were conducted by Abuameerh \& Al Saudi who concluded that there was a significant difference in student achievement motivation due to academic achievement. Graduating students show more motivation than failing students. Also, the results showed no significant differences in student achievement motivation due to gender [13].The study provides clear clues that learning motivation is an important aspect that determines student learning outcomes.

Then another study conducted by Emmanuel et al. who identifies student achievement motivation and student achievement. The results show that most high school students, who are highly motivated, have high self-concept and performed well on Mathematics achievement test. The study also found a significant relationship between self-concept and 
academic achievement which shows positive relationship between achieving motivation and academic achievement. This study confirms the importance of achievement motivation and academic self-concept with academic achievement [14].

Then, another study conducted by Chetri who identifies the relationship between achievement motivation and student achievement. The study found that there was no significant difference between achieving motivation in terms of gender and local variation, but there were significant differences in relation to management variation. Another finding of this research is that there is a correlation between achieving motivation and academic achievement also resulting in a significant relationship [15].

Another study conducted by Cloud, Noureen \& Naz which aims to test achievement and its relationship with achievement motivation and self-concept. The subjects consisted of 336 students (146 men and 172 women). The results showed that achieving motivation and self-concept significantly correlated with academic achievement. Significant gender differences were found that supported women. It is suggested that teachers should use motivational strategies to engage students in academic activities to enhance their values [16].

Research conducted by Trinora, Riswandi \& Mustakim identifies the relationship pattern between learning motivation and student learning outcomes. Based on statistical studies using simple correlations, there is a positive relationship between learning motivation and student learning outcomes. Based on statistical studies using a simple correlation with correlation coefficient, showed a tendency of higher learning motivation, the better or higher the students' learning outcomes [17].

Another research identify how motivation affects academic performance and academic achievement. Data analysis indicated relative autonomous motivation positively affects academic performance through deep strategy towards study and higher study effort. This model seems valid in medical edu- cation in subgroups such as males, females, students selected by qualitative and weighted lottery selection procedures [18].

Academic motivation that is an important factor of academic achievement is also influenced by gender. The result of the research show motivation level of female and male differed significantly [19] [20]. Research from Eymur and Geban show females got higher scores in all motivation types [21].

Academic motivation that can affect academic achievement is influenced by the home environment. The findings of the study from Muola have supported previous findings which have indicated a positive relationship between academic achievement motivation and home environment. The home environment is one of the determinants of academic achievement motivation [22]. Another research show that the home environment is one of the determinants of study habits and academic performance [23] [24].
The results of this study and the results of previous studies have shown a clear picture that learning motivation is an important aspect for achievement of student learning outcomes. Students who have a great motivation to learn will show interest, attention, concentration, perseverance, and oriented to the process and learning outcomes. Conversely, students who lack the motivation to learn will show boredom, easy to despair, and try to avoid the learning activities. Motivation to learn is very important for students because with the motivation to learn students feel more eager in learning and have a high attitude and confidence [25]. High learning motivation reveals great passion in learning, hard work, high endurance or resilience, tenacious, and diligent in learning without feeling bored let alone quickly surrender. This is certainly a special encouragement for students to develop their potential in learning so that it will have an impact on the increase of learning outcomes.

In line with the previous statement, it was revealed that students who have high motivation to learn always want to work hard to succeed without expecting reward or praise [26]. The student has a strong tendency to do something for the intrinsic satisfaction of that success. There are three factors that influence the motivation to learn, namely: (1) the beginning of the learning process; (2) learning affects stimulation; and (3) learning activities [6].

Motivation to learn has a significant influence on the intensity and quality of student learning. Motivation to learn encourages students to increase the spirit and persistence in learning. In addition, learning motivation plays a vital role in providing encouragement, passion, pleasure of the students in doing learning activities. This will certainly encourage students to improve student learning outcomes. If the motivation of student learning is low, this certainly will not cause encouragement and a sense of passion for students to learn. The most visible impact is the students' learning outcomes that tend to be low.

\section{CONCLUSION}

The results of the analysis of research data conducted in Junior High School of Yogyakarta City found that the motivation to learn has a relationship with learning outcomes in students of Junior High School of Yogyakarta City. The influence of learning motivation on learning outcomes is $21.5 \%$ while the rest is influenced by other variables. Based on the results of these studies, counselors should play a role in designing a program of tutoring services that help students motivate themselves improve student learning outcomes.

\section{REFERENCES}

[1] S, Sardjoko, S. Pembangunan Pendidikan dalam RPJMN 2015-2019 (Perpres No. 2 Tahun 2015). Jakarta: Deputi Menteri Bidang Pembangunan, Masyarakat, dan kebudayaan, 2015.

[2] Michael, Kualitas Pendidikan Indonesia Peringkat 69 Dunia, 2014. [Online 11 November 2015], Accessed from: http://www.kompasiana.com.

[3] A. E. Woolfonk. Educational Psychology. Boston: Allyn \& Bacon, 2004. 
[4] S. Pape, C. Bell, and I. Yetkin, "Developing mathematical thinking and self-regulated learning: A teaching experiment in a seventh grade mathematics classroom," Education Study Matheamtics, vol. 53, p. 179-202 ST-Developing mathematical thinking and, 2003.

[5] S. Patimah. Hubungan Motivasi Belajar dengan Hasil Belajar Siswa pada Mata Pelajaran Ilmu Pengetahuan Sosial Kelas IV SD Negeri 18/I Desa Teluk, 2014. [Online 6 October 2016], Accessed from: ecampus.fkip.unja.ac.id.

[6] R. Palupi, S. Anitah, and Budiyono, "Hubungan antara Motivasi Belajar dan Persepsi Siswa Terhadap Kinerja Guru Dalam Mengelola Kegiatan Belajar Dengan Hasil Belajar IPA Siswa Kelas Viii di SMPN N 1 Pacitan," Jurnal Teknologi Pendidikan dan Pembelajaran, vol. 2, no. 2, pp. 157-170, 2014.

[7] J. A. Glover \& R. H. Bruning. Educational Psychology: Principles and Application. Columbus: Charles E. Merril Publishing Company, 1990.

[8] W, Surakhmad. Pengantar Interaksi Mengajar Belajar. Bandung: Tarsito, 1994.

[9] E. Prayitno. Motivasi dalam Belajar. Jakarta: PPLPTK Depdikbud, 1989.

[10] M. D. Gall, J. P. Gall, R. W. Borg. Educational Research: an Introduction. New York: Longman, 2003.

[11] C. Peklaj \& M. P. Levpušček, M. P. Students' motivation and academic success in relation to the quality of individual and collaborative work during a course in educational psychology. In Anпиal ATEE Conference, 2006. [Online, 7 September 2016], Accessed from: www.pef.uni-lj.si.

[12] A. Indriani, "Pengaruh Motivasi Belajar Siswa Kelas V Terhadap prestasi Belajar Matematika di SD Negeri Bejirejo Kecamatan Kunduran Kabupaten Blora," Jurnal Ilmiah Pendidikan Matematika, vol. 4, no. 2, pp. 134-140, 2016.

[13] O. A. Abuameerh and M. Al Saudi, "The Relationship between Achievement Motivation and Academic Achievement for Secondary School Students at Salt in Jordan," Dirasat: Educational Sciences, vol. 39, no. 1, pp. 313-320, 2012.

[14] A.-O. Emmanuel, E. A. Adom, B. Josephine, and F. K. Solomon, "Achievement Motivation, Academic Self-Concept and Academic Achievement Among High School Students," European Journal of Research Reflection in Educational Sciences, vol. 2, no. 2, pp. 24-37, 2014.

[15] S. Chetri, "Achievement Motivation of Adolescents and Its Relationship with Academic Achievement," International Journal of Humanities and Social Science Invention, vol. 3, no. 6, pp. 8-15.

[16] Awan, Riffat-Un-Nisa; Noureen, Ghazala and Naz, Anjum , "A Study of Relationship between Achievement Motivation, Self Concept and Achievement in English and Mathematics at Secondary Level" International Education Studies, vol. 4, no. 3, pp.72-29, 2011.

[17] R. Trinora, R. Riswandi, \& E. Mustakim, "Hubungan Motivasi Belajar dan Hasil Belajar Siswa," Jurnal Pedagogi, vol 3, no. 1, 2015.

[18] R. A. Kusurkar, T. J. Ten Cate, C. M. P. Vos, P. Westers, and G. Croiset, "How motivation affects academic performance: A structural equation modelling analysis," Adv. Heal. Sci. Educ., vol. 18, no. 1, pp. $57-69,2013$.

[19] K. Hakan and E. Münire, "Academic Motivation: Gender, Domain and Grade Differences," Procedia - Social Behavior Science, vol. 143, pp. 708-715, 2014.

[20] C. Shekhar and R. Devi, "Achievement Motivation across Gender and Different Academic Majors," Journal of Education Developmental Psychology, vol. 2, no. 2, pp. 105-109, 2012.

[21] G. Eymur and Ö. Geban, "An investigation of the relationship between motivation and academic achievement of pre-service chemistry teachers," Education and Science, vol. 36, no. 161, pp. 246-255, 2011.

[22] J. M. Muola, "A study of the relationship between academic achievement motivation and home environment among standard eight pupils," Educational Research and Reviews, vol. 5, no. 4, pp. 213-217, 2010.

[23] N. Kakkar, "a Study of Academic Achievement in Relation To Home Environment of Secondary School Students," The International Journal of Indian Psychology, vol. 4, no. 1, pp. 3247-3253, 2016.

[24] A. O. Obeta, "Home environmental factors affecting students , academic performance in Abia State," International Journal of Academic Research and Reflection, vol. 7, no. 8, pp. 144-149, 2014.
[25] P. R. Pintrich. The Role of Goal Orientation in Self Regulated Learning. Dalam Monique Boekaerts, Paul R. Pintrich \& Moshe Zeidner (Ed.) Handbook of Self Regulation (pp. 452-502). San Diego: Academic Press, 2000.

[26] K. Amrai, S. E. Motlagh, H. A. Zalani, and H. Parhon, "The relationship between academic motivation and academic achievement students," Procedia - Social Behavior Science., vol. 15, pp. 399-402, 2011.

[27] H. B. Uno. Teori Motivasi dan Pengukurannya: Analisis di Bidang Pendidikan. Jakarta: Bumi Aksara, 2011. 